\title{
Törökország és iraki Kurdisztán kapcsolatának átalakulásai (1991-2014), 2. rész ${ }^{1}$
}

\begin{abstract}
Jelen cikk egy, az iraki kurdok és Törökország közötti kapcsolatok átalakulását elemző, kétrészes tanulmány második része. A cikk az első részben ismertetett vonalak mentén azon két kérdés megválaszolása köré szerveződik, hogy minek köszönhetően mélyült el a kapcsolat Ankara és Erbil között 2008-at követően, valamint hogy ez a folyamat mely területeken éreztette hatását. A változás kapcsán a cikk több tényezőt is azonosít. Egyrészt változás történt Törökországon belül a külpolitika mind elméleti, mind pedig gyakorlati müvelésében, amelynek következtében a hard power-elemek háttérbe szorultak a török bel- és külpolitikában egyaránt, ezzel párhuzamosan pedig a soft power-elemek egyre inkább elötérbe jutottak. Irakon belül is lényeges események zajlottak (szektarianizálódás, a turkománok háttérbe szorulása, az iraki kurdok politikai és gazdasági fejlődése), amelyek a török felet eddigi politikájának átértékelésére késztették. A Kurdisztáni Autonóm Régió és Törökország közötti kapcsolatok politikai és katonai szintjén jelentkező együttmüködési lehetőségein túl azonban a gazdaság és azon belül is az energiapolitikai kooperáció új dimenzióval bővitette a felek viszonyát. Ezen új, stratégiai elemek már kijelölik mind Erbil, mind pedig Ankara pozícióját a regionális hatalmi és gazdasági versengésben; a szoros együttmüködést és a kapcsolatok pozitív irányba mozdulását azonban a 2014-es év politikai és gazdasági összeomlása Irakban komoly kihívás elé állította.
\end{abstract}

Kulcsszavak: Törökország, Irak, Kurdisztán, AKP, Barzáni, PKK, Erbil, KDP, PUK

\section{Dudlák Tamás: The transforming relations of Turkey and Iraqi Kurdistan (1991- 2014) II.}

This article is the second part of a study dealing with the relations between the Iraqi Kurds and Turkey. The main questions are how and why the relations between Ankara and Erbil deepened after 2008. The article identifies several factors that explain the changing attitude of Turkey towards the Iraqi Kurds. On the one hand, there was a clear shift, both on theoretical and practical levels, of foreign policy-making in Turkey. As a result of these changes, hard power elements were underplayed by soft power attitudes both in the domestic and the foreign policy realms. Internal developments of Iraq (sectarianisation, the political and economic development of Iraqi Kurds, the decreasing political power of the Turkomans) also constrained Turkey to reevaluate its political attitude. Beyond working together against the PKK, there were other

\footnotetext{
A kutatás az Emberi Erőforrások Minisztériuma ÚNKP-18-3 kódszámú Új Nemzeti Kiválóság Programjának támogatásával készült, a témavezetést illetően pedig köszönettel tartozom Dr. Csicsmann Lászlónak, valamint külsős konzulensemnek, Dr. N. Rózsa Erzsébetnek. A cikk szakirodalmi bázisának biztosítása az utóbbi években folytatott utazásaimnak köszönhetően vált lehetségessé. Így köszönettel tartozom az alábbi könyvtáraknak: University of Chicago Library, Northwestern University Library, National Library of Australia, Victoria University of Wellington Library, University of California, Santa Barbara Library, SOAS Library, University of British Columbia Library, Boğaziçi University Library, a Budapesti Corvinus Egyetem Könyvtára, illetve külön köszönet a Külügyi és Külgazdasági Intézet könyvtárában Sándor Annamáriának.
} 
dimensions of cooperation between Turkey and the Kurdish Regional Government in Iraq: the fields of economy and energy policy. These new, strategic elements defined the positions of Ankara and Erbil in the regional competition for power and economic gains; however, the fateful year of 2014 challenged the positive direction of relations by posing political and economic turmoil in the Kurdistan Autonomous Region.

Keywords: Turkey, Iraq, Kurdistan, AKP, Barzani, PKK, Erbil, KDP, PUK

\section{Bevezetés}

Jelen cikk előzményében a Törökország és az iraki kurdok közti kapcsolatoknak a hidegháború végétől számított időszakát vizsgáltam egészen a 2000-es évek közepéig, amikor is az iraki kurdok de jure autonóm régiót hozhattak létre Irakon belül, és ekképpen a Törökországgal kialakított kapcsolatok jellege is megváltozott. A két tanulmány közti határként azonban mégsem ez az epizód (2005), hanem a török külpolitika 2008-ra tehető nyitása áll, minthogy azelőtt Ankara alapvetően fenyegetésként tekintett az iraki kurdok helyzetében bekövetkező pozitív változásokra, míg attól kezdve az említett felek között partneri viszony alakult ki, amely az itt elemzett időszakban (2014-ig) számos területen kiteljesedett. Jelen cikk tehát az első részben ismertetett vonalak mentén azon két kérdés megválaszolása köré szerveződik, hogy minek köszönhetően mélyült el a kapcsolat Ankara és Erbil között 2008-at követően, valamint hogy ez a folyamat mely területeken éreztette hatását?

\section{3. szakasz: a kiteljesedő kapcsolatok (2008-2014)}

\section{Törökország új Közel-Kelet-politikájának belső tényezői}

A 2000-es években három, Törökországon belül zajló folyamatot szükséges kiemelni ahhoz, hogy a török külpolitika aktivizálódását, illetve irányváltásának alapjait megérthessük. Mindezek elengedhetetlen feltételeivé váltak az Ankara és Erbil közötti kapcsolatok pozitív alakulásának. Elsőként a változáshoz elméleti alapokra volt szükség, másodszor az aktivitást belső gazdasági és társadalmi fejlődés segítette elő, harmadszor pedig a váltás végső elemének az új politikai osztálynak a külpolitikai döntéshozatal feletti hatalmának megszilárdulása bizonyult.

A 21. században megnövekedett török külpolitikai aktivitás egyik legjellemzőbb területe a Közel-Kelet, illetve a Törökországgal közvetlenül szomszédos közel-keleti országok. A 2002-től kiterjedt politikai hatalommal is rendelkező új török vezetés már idejében lefektette azokat az elméleti alapokat, amelyek az ország nagyobb aktivitását szolgálják az országot körülvevő geopolitikai térben. Az új török külpolitika alapvetéseit ennek teoretikusa, Ahmet Davutoğlu egyetemi tanár, majd külügyminiszter (2009-2014), illetve miniszterelnök (2014-2016) 2001-es Stratégiai mélység című könyve alapján az alábbiakban foglalhatjuk össze:

1. Multidimenzionalitás - többirányú kapcsolatok, kapcsolatfelvétel a lehetséges szereplőkkel. 
2. „Ritmikus diplomácia” - diplomáciai aktivitás a régi és új eszköztár együttes bevetésével (leginkább soft power és közösségi diplomácia alkalmazása révén).

3. Problémamentesség a szomszédokkal - pragmatikus kapcsolatok kialakítása, a kapcsolatok pozitív oldalának hangsúlyozása.

4. Kölcsönös gazdasági függőségek kialakítása. ${ }^{2}$

5. Értékközpontúság - a liberalizmus, az emberi jogok szerepe, a biztonság és a demokrácia összeegyeztetése.

A davutoğlui doktrína kulcsszavai a béke, stabilitás, biztonság és gazdasági prosperitás a szomszédos államokban - mindezt pedig Törökország a soft power és dialógus révén kívánja elérni úgy, hogy a kapcsolatok minden félnek kedvezők legyenek. A kapcsolatok alapját az adja, hogy Törökország az aktivitás terében található országokkal közös földrajzi térben és múltban osztozik. ${ }^{3}$ Mindezek a korábbi, passzivitásra törekvő, külvilágtól elzárkózó, úgynevezett kemalista külpolitikai elvvel szemben a 2001 utáni, többpólusúvá alakuló globális térben Törökország számára az új lehetőségekhez való alkalmazkodást és ehhez egy alternatív külpolitikai programot biztosítottak.

Az úgynevezett soft power-elemek elötérbe kerülése a török külpolitika AKP-kormány (Igazság és Fejlődés Pártja) alatti időszakában és az iraki kurdok felé való nyitás során különösen hangsúlyosan jelent meg. Az iraki kurdokkal való egyre aktívabb kapcsolatok létrejöttében azonban nem feltétlenül a török állam soft power-ereje volt a kulcstényezö, hanem a gyakorlatban az állam diplomáciai szerepvállalása helyett a társadalom kezdeményező elemei kerültek kulcspozícióba a külkapcsolatok alakításában. Ennek eredményeképpen a hagyományos állami diplomácia kiegészültt ${ }^{4}$ a közösségi diplomácia elemeivel, ami jelen esetben különös jelentőséggel bír. A kurdkérdés érzékenysége miatt ugyanis Törökország számára diplomáciailag kevésbé járható út volt, hogy az állam egy számára előkészítetlen és ismeretlen terepen lépjen fel a kapcsolatok kezdeményezőjeként egy nem állami szereplővel, a Kurdisztáni Regionális Kormányzattal (a továbbiakban: KRK) szemben. Ezért voltak elengedhetetlenek a török-iraki kurd kapcsolatok kialakításában és fejlesztésében azok a vállalkozó szellemü üzletemberek, akik a felek közti gazdasági kapcsolatok megalapozásával közvetítői és részben kikényszerítői lehettek a későbbi politikai nyitásnak. ${ }^{5}$ Az iraki kurdok és Törökország között zajló gazdasági interakció kiválóan megmutatja, hogy két ország viszonya miként szervezhető pragmatikus érdekek mentén, és hogyan vált a török üzleti tevékenység és az erre mutatkozó iraki kurd fogadókészség a Kurdisztáni Autonóm Régióval szemben folytatott török külpolitika átalakítójává és integráns részévé.

BALOGH et al.: Kapacitások és ambíciók: a török közel-keleti külpolitika alapjai, MKI-elemzések, E-2013/9. 2. o.

Marianna Charountaki: Turkish Foreign Policy and the Kurdistan Regional Government, Perceptions, 17. évf., 2012/4, 195. o.

4 Míg általánosságban a hagyományos állami diplomácia közösségi diplomáciával való kiegészüléséről beszélhetünk, addig török-iraki kurd viszonylatban a 2000-es évek közepén inkább az előbbi hiánya és az utóbbi kulcsszerepe írja le jobban a valóságot.

5 Merve Özdemirkiran: Soft Power and the Challenges of Private Actors: Turkey - Kurdish Regional Government (KRG) Relations and the Rising Role of Businessmen in Turkish Foreign Policy, European Journal of Turkish Studies, 2015/21, 2. o. 
A gazdasági kapcsolatok fejlesztésében élenjáró üzletemberek között kimondottan fontos szerep jutott a törökországi kurdoknak, akik a kulturális és nyelvi háttéren túl a nemzeti összetartozás érzése által is motiválva foghattak bele a Kurdisztáni Autonóm Régiót érintő üzleti céljaik megvalósításába. Az Erbil felé irányuló gazdasági nyitásban ők javarészt a kis és közepes méretű vállalkozásokat képviselték, míg a nagyobb méretü, etnikailag török vezetésű vállalatok Törökország nyugati végéből, a kurdokat követve jelentek meg Északkelet-Irakban. A kurd kapcsolatokban a legnagyobb szerep a 2000-es évek végén a gaziantepi és diyarbakıri kereskedelmi kamarák szervező tevékenységének jutott. Az ezekben részt vevő üzletemberek egyszerre voltak diplomaták, közvetítők és információforrások; és az ő előzetes tapasztalataikra és terepismeretükre a török kormány később a politikai kapcsolatok kiépítésekor is támaszkodhatott. ${ }^{6}$

Ezeket a befektetőket ráadásul a 2008-as gazdasági világválság negatív hatásai még inkább érdekeltté tették az új, közel-keleti üzleti lehetőségek keresésében. ${ }^{7}$ A 2000-es évek végére a törökök már tanúi lehettek az elhúzódó európai uniós tárgyalási folyamatnak; így az európai piacokkal való szabadkereskedelem lehetősége reálisan a távoli jövőbe tolódott, a török kereskedők és befektetők pedig új, „,nem hagyományos” irányokba terelték külgazdasági aktivitásukat. Ennek egyik legjellemzőbb terepe a Közel-Kelet lett, ahol a török kereskedők profitálhattak a növekvő potenciállal (népességszám, vásárlóerő, bővülő szolgáltatások) bíró, felemelkedő piacok kínálta lehetőségekből. Az egész folyamatnak a török gazdaság dinamikus növekedése adott hajtóerőt, amelynek legfőbb és e tekintetben legaktívabb szereplői az új, vallásos kapitalista üzleti réteg, az úgynevezett anatóliai tigrisek voltak. Ezek a kis- és középvállalkozók exportorientált politikát valósítottak meg, és a keleti piacokon képesek voltak tevékenységüket hosszú távon megalapozni - annak is köszönhetően, hogy ezeken a területeken a nyugati cégek versenyével kevésbé kellett szembenézniük. Az AKP-rendszer egyik legfőbb támogatóivá avanzsált kereskedök ${ }^{8}$ térnyerése hozzájárult ahhoz, hogy a török külpolitikában egyre hangsúlyosabban jelentek meg a kereskedelmi és üzleti érdekek, valamint a közösségi diplomácia. ${ }^{9}$ A török diplomácia és külpolitikai célrendszer - hagyományos, az ország védelmére vonatkozó feladatai mellett - tehát kiegészült a kereskedelmi érdek képviseletével is. Ezt a Törökország esetében a 2000-es években kialakuló jelenséget a szakirodalom a „kereskedőállam” felemelkedéseként ${ }^{10}$ aposztrofálja.

Törökországban tehát az AKP kormányra kerülésével egy új, ideológiai hátterét vallási alapokon meghatározó „ellenelit”11 pozícióinak kiépítése kezdődött meg. Ez a pozícióharc azonban nyilvánvalóan nem korlátozódott csupán a gazdasági szférára; az iszlamista

ÖZDEMIRKIRAN: $i . m ., 9$.

ÖZDEMIRKIRAN: $i$. m., 7-8.

Mehmet ŞAHIN: 'Anadolu kaplanları' Türkiye’yi Ortadoğu ve Afrika’da etkili kılıyor” [Az 'anatóliai tigrisek' a török közel-keleti és afrikai befolyás szolgálatában]. Ortadoğu Analiz, 2. évf., 2010/17, 95. o.

9 Dudlák Tamás: A török déli nyitás politikája: Soft power eszközök Afrikában, Afrika Tanulmányok, 12. évf., 2018/1-3, 31-54. o.

10 Kemal KIRIşçI: The Transformation of Turkish Foreign Policy: The Rise of the Trading State, New Perspectives on Turkey, 40. évf., 2009/tavasz, 43. o.

11 Sara Salahaddin Mustafa - Sardar AzIz: Turkey and the Iraqi Kurdistan. Bonds of Friendship. In: Alex DanilovicH (szerk.): Iraqi Kurdistan in Middle Eastern Politics, Routledge, London, 2016, 138. o. 
vezetés a politikai, döntéshozatali szféra teljes bekebelezését is célul tűzte ki. A török „mély állam" (derin devlet) kifejezés arra utal, hogy az állami döntéshozatalban közvetlen vagy közvetett módon nem demokratikus elemek (a hadsereg) is szóhoz jutottak. ${ }^{12}$ Ez a nem intézményesített, láthatatlan hatalmi befolyás 2007 elött arra sarkallta a politikusokat, hogy jobb elkerülni a politikában olyan irányokat, amelyek a döntéshozatalban a legnagyobb, kvázi vétóhatalommal bíró hadsereg érdekeit, ideológiai irányvonalát, illetve a Török Köztársaság kemalista felépítményét (az 1982-es alkotmányt) sértenék. Mindezen korlátok között a kurdok mint törökországi kisebbség elismerése lehetetlen volt, és ugyanezen gondolat mentén a szomszédos országok kurdjaival kialakított pozitív kapcsolat is a kemalista katonai vezetés vétóját vonhatta maga után.

A kezdeti politikai konfliktusokat követően 2007 és 2008 folyamán az iszlamista demokratikus politikai vezetés és a kemalista „mély állam” között kenyértörésre került sor, amelyben az AKP demokratikus úton biztosította népszerűségét (úgynevezett e-memorandum) és sikeresen fogta perbe a katonai vezetés prominens tagjait (Ergenekon- és Balyoz-ügyek). A katonaság ekkor többször is sikertelenül próbálkozott beavatkozni a török belpolitikába, a civil kormány viszont a nemzet többségének támogatását maga mögött tudva hiteltelenítette a hadsereg lépéseit. A katonaság csökkenő befolyása kétségkívül megújuláshoz vezetett az állami döntéshozatalban, az Európai Unió elveivel összhangban nagyobb civil kontrollt eredményezett az állami ügyek és legfőbbképpen a külpolitika fölött. Ez a fontos belső változás lehetővé tette a külpolitikai orientációváltást Törökország számára, vagyis azt, hogy új szemléletet alakítson ki és alkalmazzon az iraki kurdokkal való kapcsolatában. A kurdokkal kapcsolatos, korábbiaktól eltérő politika mindenekelőtt azonban először a hazai környezetben éreztette hatását.

Az új Közel-Kelet-politika a török külpolitikát évtizedek óta meghatározó kurdkérdéssel összefüggésben is tehát egy új irányvonal lefektetését tüzte ki célul. A török kormánypárt iszlamista ideológiai háttere révén eleve lehetővé vált, hogy kurd származású választók nagyobb arányban támogassák a pártot - amennyiben számukra a törökországi kurdok és törökök közti közös nevező, az iszlám ügyének támogatása fontosabb volt, mint a kurd nacionalizmus Törökországon belüli erősítése. Az a tény, hogy az AKP szavazói között a kezdetektől fogva jelentős számú etnikai kurd népességet is találunk, a párt döntéshozói számára meghatározó szempontot jelentenek a politikai irányvonal kialakításában.

Bár a PKK-t (Kurdisztáni Munkáspárt) az Európai Unió is terrorszervezetként ismerte el, maga a kurd mozgalom Törökországban jócskán támaszkodhatott az Európai Unió kínálta eszközökre az országon belüli politikai érdekérvényesítés kiterjesztése céljából. Törökország 1999-ben ugyanis megkezdte az európai uniós csatlakozási tárgyalásokat, és ez a fejlemény alapvető hatással volt a törökországi kurd mozgalom (beleértve a PKK-t is) politikai orientációjának kialakításában. A katonaság politikai szerepének visszaszorítása révén pedig lehetőség nyiltt a kurdkérdés biztonsági dimenziójának háttérbe szorítására. ${ }^{13}$

KIRIŞÇI i. m., 41.

13 A katonaság kiemelkedő szerepe a török politika alakításában mind a kurdok által képviselt állandó biztonsági kihívásnak, mind pedig a hidegháborús környezetnek köszönhető volt. És bár a hidegháború véget ért, a török hadsereg mégis fenntartotta komoly költségvetési és állománybeli pozícióit, sőt azokat jócskán növelte is. 
A kurd békefolyamat (vagy ahogy a török kormányzati körökben emlegették: „demokratikus nyitás") 2009-es megindulása ${ }^{14}$ már ennek az új megközelítésnek az előtérbe kerülését fémjelezte Törökországban. A békefolyamat eredményeképpen a törökországi kurdok számára lehetővé tették a kurd nyelv használatát a magániskolákban, a választási kampány során és a médiában. 2012 legvégén Erdoğan bejelentette, hogy a török Nemzeti Hírszerzési Hivatal (MİT) a PKK vezetőjével, az 1999 óta török börtönben lévő Abdullah Öcalannal megkezdte a tárgyalásokat. Az egyeztetések, amelyek általános politikai és társadalmi támogatást élveztek Törökországban, 2013 márciusában oda vezettek, hogy a kormány új pozíciójára reagálva Öcalan fegyverszünetet jelentett be, amelyet 2015 közepéig a felek komolyabb konfliktus nélkül be is tartottak. ${ }^{15}$

\section{A politikai kapcsolatok átalakulása az Ankara-Bagdad-Erbil három- szögben}

A 2000-es évek közepén a régi és az új elit párhuzamos törökországi jelenlétének idején egymásnak ellentmondó hangvételü kijelentésekről adhatunk számot. Az mindenesetre a 2000-es évekre egyértelművé vált, hogy a törökországi kurdkérdés rendezésére tett állami kísérletek - amelyek a kérdést csupán katonai szempontból közelítik meg - nem hozhatják el a kívánt eredményt, a béke helyreállítását. ${ }^{16}$ Ezt maga Erdoğan is elismerte, amikor 2005. augusztus 12-én kijelentette Diyarbakırban, hogy a PKK problémája csupán katonai eszközökkel nem oldható meg. ${ }^{17}$ Abdullah Gül 2005. november 15-ei beszédében már tanúi lehetünk az iraki kurdokról kialakított török percepció megváltozása kezdetének, amikor Gül a török nép „kurd eredetű iraki testvéreiről” tett említést. ${ }^{18}$

A török titkosszolgálat 2005. október 20-án kezdte meg a titkos tárgyalásokat az iraki kurd vezetéssel a kapcsolatok felvételének mikéntjéről, a közös érdekek és problémák egyeztetéséről. Áttörés azonban ekkor még nem következett be: a katonai vezetés képviselői, Yaşar Büyükanıt, illetve İlker Başbuğ még 2007 folyamán is elmarasztaló volt az iraki kurdokkal szemben. ${ }^{19}$ Ráadásul a Kirkukról és környékéről történő népszavazást eredetileg 2007. november 15-ére tervezték, ezért Ankara 2007. április 27-én katonai beavatkozással fenyegette meg a KAR-t, amennyiben Kirkukot a népszavazás eredményképp az autonóm tartományhoz csatolják. A 2007-es év amúgy is meglehetősen feszült légkörben zajlott a felek között, és ez a civil kormány retorikájának szintjén is megmutatkozott: Erdoğan 2007 augusztusában kijelentette, hogy nem kíván találkozni törzsi vezetőkkel, köztük

14 2009. január 1-jén maga Erdoğan kurd nyelven nyitotta meg a kurd nyelvű TRT-6 müsorát. David L. PHILLIPS: Confidence Building Between Turks and Iraqi Kurds, Atlantic Council, 2009, 9. o.

15 Bár Öcalan nyomására a PKK fegyverei elhallgattak Törökországban, ez azzal is együtt járt, hogy a PKK-milíciák az észak-szíriai és észak-iraki bázisaikra vonultak vissza, így azok teljes leszerelése nem történhetett meg. Gönül ToL: Untangling the Turkey-KRG Energy Partnership: Looking Beyond Economic Drivers, Global Turkey in Europe II, Edizioni Nuova Cultura, 2014, 3. o.

16 Helin Sarı Ertem: Kuzey Irak’tan 'Irak Kürdistanı'na Ankara-Erbil İlişskilerindeki Dönüşümün Siyasi ve Ekonomik Temeller. In: Özden Zeynep Oктаv - Helin Sarı Ertem (szerk.): 2000'li Yıllarda Türk Dış Politikası: Fırsatlar, Riskler ve Krizler, Nobel Yayınları, İstanbul, 2015, 299. o.

17 Phillips: i. m., 8.

18 ERTem: i. m., 303.

19 ERTEM: i. m., 304. 
Barzánival..$^{20} \mathrm{~A}$ török miniszterelnök a KRK elnökét ekkoriban még a PKK-val való együttmüködéssel is megvádolta. ${ }^{21}$

2008 előtt tehát általánosságban az iraki kurdokra olyan fenyegetésként tekintett a török vezetés, amelyet kordában kell tartani. Ugyanakkor a 2000-es évek közepére már bebizonyosodott, hogy Törökország számára a jelenlegi keretek között lehetetlen az iraki kurdok autonómiájának visszaszorítása, megnövekedett politikai hatalmának és nemzetközi jelentőségének csorbítása. Az iraki alkotmány által teremtett új regionális realitást ugyanis az Amerikai Egyesült Államok és általában a nemzetközi közösség védelmezte, így az ahhoz történő igazodás jelenthette Ankara számára az egyetlen járható (kevésbé költséges) utat.

Ankara számára a pszichológiai áttörést az jelentette, amikor az új külpolitikai vezetés elfogadta az új iraki realitást. A puszta elfogadáson túl azonban az új helyzet kiaknázására is lehetőség mutatkozott. A KAR felemelkedésével a kurd nemzeti önrendelkezési diskurzust immáron ugyanis nem csupán a PKK dominálja, hanem megjelent egy olyan alternatív erő is, amely eltérő ideológiai alapon (demokrácia mellett elkötelezett, szabadpiaci kapitalizmusra nyitott konzervativizmus) valós alternatívát kínálhat az autonómiára vágyó kurdoknak. Ráadásul, adott esetben, ennek az alternatívának a támogatása még az állandó belső ellenség, a PKK ellen is hasznositható lehet.

Ankara új megközelítésének - amelyhez az elméleti háttér Davutoğlu munkássága révén már régóta rendelkezésre állt - föpróbájához a PKK 2007. végi támadásai szolgáltattak lehetőséget. 2007. október 7-én a PKK rajtaütést hajtott végre a délkelet-törökországi Şırnakban 13 török katona halálát okozva. Két héttel ezt követően a PKK Hakkarıban ölt meg 12 katonát, valamint 8-at elfogtak. A PKK-nak ezek az iraki határ menti támadásai nyomás alá helyezték a török kormányt, ugyanakkor a PKK elleni hatékony fellépésre Törökország területe nem volt elegendö, nyilvánvaló volt, hogy a PKK iraki bázisait és utánpótlási vonalait is gyengíteni kellett ahhoz, hogy a jövőben a hasonló merényleteket ellehetetlenítsék. Az események súlyosságát látva egy esetleges észak-iraki határmenti beavatkozásra a török parlament már 2007. október 17-én felhatalmazást adott a hadseregnek. ${ }^{22} \mathrm{Az}$ amerikai vezetés a korlátozott légitámadásokhoz hozzájárult, ugyanakkor a török szárazföldi hadművelet tervét nem támogatta. Mindenesetre a török válaszlépés elökészítése segítette mind az amerikaiakkal, mind pedig az iraki kurdokkal való kapcsolatok javítását. A török kormány végül az egyeztetések eredményeként zöld utat kapott, így egyszerre támadhatta katonailag a PKK állásait (2008 februárjában a Záb folyó felső szakaszánál), illetve vethetett be diplomáciai eszközöket a militáns kurd szervezet elszigetelésére. ${ }^{23}$

20 Charountaki: $i . m ., 191$.

21 Ipek Demir - Welat ZeydanlioğLu: On the Representation of 'Others' at Europe's Borders: The Case of Iraqi Kurds, Journal of Contemporary European Studies, 18. évf., 2010/1, 7-23. o. Erdoğan nyilatkozataira általában jellemző, hogy különböző nyelvhasználat jellemzi attól függően, hogy hazai vagy külföldi közönség számára beszél. MustAFA-AzIz: i. m., 138.

22 PhilliPs: $i . m ., 19$.

23 Mesut Özcan: From Distance to Engagement: Turkish Policy towards the Middle East, Iraq and Iraqi Kurds, Insight Turkey, 13. évf., 2011/2, 76-78. o. 
Az együttmüködés részeként a KAR látványos lépéseket tett a $P K K$ iraki tevékenységének korlátozására: a PKK-tól a pesmergák átvették az ellenőrzőpontok müködtetését, valamint Erbilben és Szulejmánijében bezáratták a PKK-hoz köthető pártszervezeteket (DSP). ${ }^{24}$

Ankara tehát a PKK támadásaira megfontoltan, több szinten, a regionális szereplőkkel egyeztetve reagált. Ez az egyoldalú cselekvés helyett megvalósított többirányú nyitottság ahhoz vezetett, hogy Törökország Irak viszonylatában 2008-at követően mind a kurdokkal, mind pedig a központi kormányzattal konstruktív viszonyt alakított ki. Törökország ekkor tulajdonképpen nem csinált mást, mint eddigi legfőbb politikai céljának - a PKK iraki tevékenységének korlátozása - mélyebb beágyazottságot keresett, és ekképpen támogatókkal együtt vette fel a harcot régi ellenlábasa, a PKK ellen Irakban.

Azt láthatjuk tehát, hogy az 1990-es évek ad hoc jellegü török-iraki kurd kapcsolatait 2008-tól egy strukturált megközelítés váltotta fel Ankarában. Míg az 1990-es évek kapcsolatainak alacsony szintjét az is meghatározta, hogy az elhúzódó iraki kurd polgárháború nem tette egyértelművé, melyik iraki kurd szereplő kerül domináns pozícióba Észak-Irakban, addig 2003-at követően a kurdok dominanciája az iraki politikai színtéren egyértelmü volt, a török külpolitika mégis csak komoly késéssel vette tudomásul ezt a tényt.

Amennyire feszült év volt a török-iraki kurd bilaterális kapcsolatokban a 2007-es év, 2008 már az átalakulások éve lett. 2008. május 1-jén a biztonsági ügyeket illetően is áttörés következett be: Bagdadban Törökország és a KRK magas rangú képviselői elöször folytattak egyeztetéseket. A 2008-2009-es években a kapcsolatok komoly felívelésének lehetünk tanúi török-iraki viszonylatban is; a török és az iraki kormány több biztonsági, gazdasági és energiapolitikai tárgyú együttmüködési nyilatkozatot írt alá. ${ }^{25}$ 2008-ban nyitották meg Moszulban a török konzulátust. Ugyancsak 2008-ban a Turkish Airlines újraindította az 1991 óta szünetelő közvetlen bagdadi járatát. A határ menti török beavatkozás után 2008. március 7-én az iraki elnök, a PUK vezetöje, Dzsalál Talabáni járt Ankarában. Ezt 2008. július 10-én Erdoğan miniszterelnök bagdadi látogatása követte. Núri al-Máliki iraki miniszterelnök (2006-2014) - aki ekkor a PKK-t az al-Káidához hasonlította - támogatásáról biztosította Ankarát a PKK elleni harcban, ahhoz viszont nem járult hozzá, hogy a török csapatok észak-iraki beavatkozása rendszeres legyen, mint Szaddám Husszein idején. ${ }^{26}$

A következő években mind a török-iraki, mind pedig a török-iraki kurd államközi kapcsolatok további dinamizálódásának lehetünk tanúi. Az Ankara és Erbil közötti bilaterális kapcsolatokban új időszámítás kezdetét jelentette 2009 októberében a török külügyminiszter, Ahmet Davutoğlu erbili látogatása, amelyet 2010-ben Maszúd Barzáni törökországi látogatása követett. 2010. március 11-én az erbili török konzulátus megnyitása már

24 Phillips: $i$. m., 20.

25 Charountaki: $i$. m., 192. Párhuzamosan egyre aktívabb török szerepvállalás indult meg Szíria vonatkozásában is; a török vezetők pedig ekkor már egy társadalmilag és gazdaságilag integrált közel-keleti övezet létrehozását vizionálták, ahol a határok is eltünnek az egyes országok között. Ennek a tervnek a legfőbb motivációt a „nyugati világ” 2008-as gazdasági válsága adta, amely mind Törökországot, mind pedig a Közel-Kelet más területeit sokkal enyhébben érintette, mint a „hagyományos” török piacokat, Európát.

26 Phillips: i. m., 11.; Máliki a PKK-t az al-Káidához hasonlította. 
a kapcsolatok egy új szintjét jelezte elöre. Ezzel a török kormány tulajdonképpen szimbolikusan is elismerte a KAR autonóm státuszát. ${ }^{27}$

2009. október 15-én zajlott Erdoğan történelmi látogatása, amely több tekintetben is úttörő jelentőségű volt. Külföldi vezető az iraki történelemben elöször tartott beszédet a parlamentben. Elsőként a történelemben egy szunnita vezető síta emlékhelyet látogatott meg. ${ }^{28}$ Ugyanekkor Erdoğan Erbilbe is ellátogatott - ez volt az első alkalom, hogy török vezető Kurdisztánban járt. Ez a nagyon komoly üzenetértékü körút, a török szándékokat jól tükrözte; egyrészt egyértelműsítette a török szándékokat a közelgő iraki parlamenti választások (2010. március 7.) kapcsán, másrészt előrevetítette a 2011-es amerikai csapatkivonásokat követően betölteni tervezett török szerepvállalást Irakban.

2008-at követően tehát a török külpolitika Irak vonatkozásában eljutott a „megkülönböztetés politikájáig”: Bagdad és Erbil különválasztása kétségtelenül komoly pszichológiai gátat tört át a török külpolitikai vezetésben. ${ }^{29} \mathrm{Ez}$ a multilaterális elv a későbbiekben pedig kifizetődőnek bizonyult: Ankara ugyanis egyértelműen Erbil mellett tette le a voksát, amikor kapcsolatai a 2010-es iraki parlamenti választásokat követően megromlottak az iraki központi kormányzattal.

Az Ankara-Bagdad-Erbil háromszög dinamikáját bonyolítja a javarészt a KAR-ban élő iraki turkománok ${ }^{30}$ helyzete és politikai orientációi. A török vezetés számára az iraki turkománok érdekeinek védelme hagyományosan kiemelt fontosságú (legalábbis a nyilatkozatok szintjén), így a 2003-as amerikai beavatkozással egyidőben Ankarában az iraki turkománok pozíciójának romlását vizionálták, ${ }^{31}$ és a megerősödő iraki kurdok és a helyi turkománok közti harcok kiújulását jósolták. (A két etnikum közti szembenállásnak történelmi gyökerei vannak; ennek egyik legemlékezetesebb momentuma a kirkuki turkománok ellen elkövetett 1959-es atrocitások.) Az etnikai feszültségekhez Ankara az iraki turkománok részére szóló állítólagos fegyveres támogatással is hozzájárult. ${ }^{32}$

Az 1991-ben Ankara támogatásával alapított, turkomán politikai csoportokat és pártokat egyesítő Iraki Turkomán Front (ITF) szerint Irakban mintegy 5 millió turkomán

27 Jogilag az autonómia elismerése az iraki alkotmány elfogadásával Törökország részéről már 2005-ben megtörtént, sőt Recep Tayyip Erdoğan miniszterelnök (2002-2014) abban az évben tartott diyarbakıri beszédében beismerte, hogy Törökország rosszul kezelte a kurdkérdést. ToL: i. m., 3.

28 Törökország részéről az iraki síták irányában a kapcsolatok erősítése már Erdoğan 2010. decemberi, illetve 2011. januári kerbelai, illetve nedzsefi látogatásakor megkezdődött. Nedzsefben Erdoğan mint vezető pozícióban lévő szunnita muszlim a világon elsőként imádkozott Ali imám sírjánál. Graham E. FulLer: Turkey and the Arab Spring: Leadership in the Middle East, Bozorg Press, 2014, 297. o.

29 Innentől kezdve a török külpolitikai gondolkodás Irak kapcsán három politikáról beszél, elkülönítve Irakon belül a síitákkal (központi kormány), a szunnita arabokkal (Északnyugat-Irak) és a kurdokkal (Északkelet-Irak) kapcsolatos politikákat. Az Iszlám Állam 2014-es iraki előretörése kapcsán az iraki „játszma” immáron négyszereplőssé vált a török vezetés számára. Ali BALCI - Recep Tayyip GüRLER - Zana BAYKAL: Türkiye’nin Irak Politikası 2015. In Burhanettin Duran - Kemal İNAT (szerk.): Türk Dış Politikası Yilliğı 2015. SETA Yayınlar, Istanbul, 2016, 64. o.

30 Ez az etnikum türk nyelvet beszél és ekképpen a törökországi törökök (nyelv)rokona. A turkománokra gyakran hivatkoznak türkménekként, ám ennek használata zavarhoz vezet, mivel utalhat a modern Türkmenisztán lakóira is. Ennek elkerülése érdekében is a továbbiakban konzekvensen a turkomán megnevezést használom.

31 Phillips: i. m., 10.

32 Asa Lundgren: The Unwelcome Neighbour: Turkey's Kurdish Policy, I. B. Tauris, London - New York, 2007, 92. o. Miután a hivatalos török álláspont szerint a török állam területén nincsenek etnikai kisebbségek, így Ankara etnikai alapon meghatározott iraki politikája meglehetősen ellentmondásosnak bizonyult. Irak esetében ez a helyi turkománok támogatásában merült ki, akik Ankara szemében eleinte alkalmasnak bizonyultak arra, hogy az észak-iraki kurd hegemóniát csökkentsék. LUNDGREN: i. m., 89. o. 
található. Ez a szám nyilvánvaló túlzás, és az ITF korlátozott lehetőségeit jól jellemzi, hogy a 2005-ös parlamenti választásokon csupán a szavazatok 0,87\%-át kapták. A szervezet gyenge érdekérvényesítő képessége oda vezetett, hogy Törökország egyre inkább kihátrált a szervezet hathatós támogatása mögül, minthogy sem a párt, sem pedig a turkománok nem voltak képesek érdemben befolyásolni az iraki belpolitikát, és így érvényesíteni Ankara érdekeit. ${ }^{33}$ A török vezetés számára egyértelmüvé vált, hogy ha Irakban befolyást kíván szerezni, más politikai csoportokra kell támaszkodnia Bagdadban.

Ekkor kerültek előtérbe a szunnita csoportosulások, amelyek alternatívát jelenthettek volna az Irakban 2003 után többséghez jutó síita vezetéssel szemben. A szunnita politikai erők azonban a 2010-es parlamenti választásokon alulmaradtak, így Törökország újabb partner felé nyitva az iraki kurdok támogatása mellett tette le voksát. Jóllehet már a 2005-ös iraki parlamenti választások is megmutatták, hogy a kurdok iraki belpolitikában betöltött jelentősége megnőtt, Ankara az Irakon belüli új hatalmi változásokra csak meglehetősen lassan reagált.

Az Ankara és Bagdad közti bizalomépítő politika végét mindkét fél részéröl éppen az iraki választások következtében kialakuló politikai helyzet hozta. Ezt követően ugyanis számos vonatkozásban ${ }^{34}$ érdekellentét alakult ki a partnerek között. Ezek nem csupán az iraki szektarianizmus ${ }^{35}$ újrafellángolásában öltöttek testet, hanem a szíriai válságban elfoglalt ellentétes török és iraki pozícióban is, minthogy Ankara az Aszad-kormány ellen felkelők egyik legfőbb támogatójává lépett elö. Máliki a 2011 tavaszától kirobbant szíriai válságban a szektarianizálódás fellángolását látta, és az ottani konfliktusba beavatkozó szunnita hatalmakat (öbölországok, illetve Törökország) azzal vádolta, hogy szektariánus alapon politizálnak, és így a régió biztonságát fenyegetik. Máliki ezen a szemüvegen keresztül látta az iraki helyzetet is, ezért itt is egyre bizalmatlanabbá vált Törökországgal szemben. A síitákat és Iránt erőteljesen elötérbe helyező politikáját részben erre való reakcióként, részben pedig az amerikai kivonulás teremtette lehetőségek - kisebb kontroll az iraki kormány és a hadsereg felett - következtében indította el. A biztonsági helyzet - akárcsak a szomszédos Szíriában - Irakban is jelentősen romlott a 2011-es amerikai csapatkivonást követően, föképpen a szunnita területeken, ahol - részben válaszul a síita központi kormány elnyomó intézkedéseire - a radikális terrorszervezetek töltötték be a létrejövő hatalmi űrt - ez pedig Bagdad számára további ellenlépések megtételéhez nyújtott alapot.

Az Ankara és Erbil közti politikai kapcsolatok szorosabbá válása a 2010-es évek elején tehát természetes következménye volt annak, hogy Ankara viszonya mind Bagdaddal, ${ }^{36}$

33 Phillips i. m., 18.

34 Ezek közé tartozott az is, hogy Ankara menedéket adott az egykori iraki alelnöknek, Tarek al-Haseminek.

35 Törökország még az iraki síita vallási vezetőkkel is felvette a kapcsolatot, Irak-politikáját egyértelmüen a szektariánus és etnikai ellentéteken túlmutató megközelítés jellemezte (például a Nemzeti Iraki Szövetség támogatása). ÖzcAN: i. m., 88.; Törökország az iraki szunniták és síiták közti konfliktusban való közvetítés érdekében az Iszlám Konferencia Országai (OIC) szervezetére is támaszkodott, amelynek a vezetője ekkor a török Ekmeleddin İhsanoğlu volt - kevés sikerrel. Fuller: i. m., 298.

36 Az iraki Maliki-kormányzattal 2012 végén annyira megromlott a viszony, hogy a török külügyminiszter, Ahmet Davutoğlu gépét az irakiak nem engedték, hogy leszálljon Erbilben. Emre TunçALP: Turkey’s Natural Gas Strategy: Balancing Geopolitical Goals \& Market Realities, Turkish Policy Quarterly, 14. évf., 2015/3, 73. o.; Az igazsághoz viszont az is hozzátartozik, hogy Davutoğlu Erbilben úgy látogatta meg a kurd partnereket, hogy arról az iraki külügyminisztert nem értesítette. Charountaki: i. m., 193. 
mind pedig Damaszkusszal (al-Aszad kormánya) erőteljesen megromlott. Ezen túl Szíriában a török vezetés számára kedvezőtlenül alakultak a fejlemények: a szíriai kurdok közötti frakcióharcokból egyre inkább a PKK-val szoros kapcsolatot ápoló PYD tünt ki mint domináns elem. A PYD-vel szemben Ankara már 2011-től egy alternatív (török szövetséges, Aszad-ellenes) kurd politikai projekt beindításán fáradozott, és ehhez Erbilben partnerre találhatott. Törökország 2012-ben a Barzáni-kormány segítségével kívánta a szíriai konfliktus keretei között a szíriai kurd ellenzéket megszervezni. Ebben a várakozásában azonban Ankarának csalódnia kellett, minthogy a KDP nem rendelkezett a megfelelö mértékü szíriai kapcsolattal, hogy a rivális szíriai PYD-re rákényszerítse akaratát. ${ }^{37}$ Ezt a sikertelen kísérletet követően tehát Ankara egyre inkább rákényszerült a szíriai szunnita csoportok támogatására a szíriai kormány megbuktatása érdekében. Mindez az iraki síta vezetés számára egy újabb jele volt annak, hogy Ankara szektariánus alapon szervezi közelkeleti politikáját. ${ }^{38}$

Ankara és Erbil kapcsolatának elmélyüléséhez az is hozzájárult, hogy Irakban a 2010-es választásokat követően a Máliki elleni arab ellenzék ereje meggyengült (a Tarek al-Hasemiféle mozgalom politikai ellehetetlenülése és Hasemi száműzése), így a Bagdaddal fennálló érdekellentétek - és általában a török érdekek - Irakon belüli képviselőjének szerepét egyre inkább Erbil kezdte átvenni. Erre az iraki kurdok amúgy is egyre alkalmasabbnak mutatkoztak, minthogy az amerikai kivonulás után jelentősen megromlott a viszonyuk a központi kormányzattal, így Törökországban törekvéseik támogatójára lelhettek.

\section{Kereskedelem és soft power: Ankara és Erbil}

A Szaddám-rezsim bukásával az iraki kurdokat sújtó kettős embargó megszűnt, ezzel párhuzamosan pedig a gazdaságilag felemelkedö Törökország új üzleti lehetőségeket kínált a vállalkozóbb szellemű irakiak számára. Az átjárhatóbb határok miatt ezek a vállalkozások hamar kifizetődővé váltak, így egyre intenzívebb tőkeáramlás és kereskedelem kezdődött Észak-Irak és Törökország között. Az új helyzet mind a nagyvállalatok, mind pedig a kiskereskedők számára előnyökkel kecsegtetett. Ez a két fél közötti megnövekedett teherforgalomban is megnyilvánult: míg 2001-ben 93.404 kamion lépte át a határt Törökországból Irak felé, addig ez a szám 2004-re elérte a 253.764-et, 2010-ben pedig az 482.563-at. ${ }^{39}$

Az észak-iraki területek és Törökország közti kapcsolatokban azonban fontos különbség mutatkozott az iraki központi kormány ellenőrzése alá tartozó területek és a KAR területei között: az előbbiek egyre kockázatosabbnak bizonyultak a kereskedelem számára; rendszeressé váltak ugyanis a török kamionsoförök ellen elkövetett gyilkosságok az északi Ninive tartományban. Ezzel szemben a KAR ellenőrzése alá tartozó területeken ilyen atrocitások nem érték a török kereskedőket, így azok figyelme Irakban egyre inkább e biztonságos terület felé fordult.

TOL: i.m., 4.

FULLER: i. m., 300.

39 Damla B. AKSEL - Didem DANış: Diverse Facets of Europeanization at the Iraqi-Turkish Border. In: Nurcan Özgür BaklacioĞLu: Migration, Asylum, and Refugees in Turkey: Studies in the Control of Population at the Southeastern Borders of the EU, Mellen Press, 2014, 285-287. o. 
A gazdasági és politikai kapcsolatok javulásának körkörös, egymást erősítő folyamatában fontos kiemelni a két fél között kiépülő infrastrukturális összeköttetést is: 2010-ben közel 100 év után újraindult a törökországi Gaziantepből az észak-iraki Moszulba tartó közvetlen vonat, és ezzel egyidőben a Turkish Airlines közvetlen járatott indított Isztambul és Erbil, valamint Isztambul és Szulejmánije között. ${ }^{40}$ Ezzel együtt is azonban olykor a kereskedelmi érdekek érvényesülésének még mindig komoly akadályát jelenti a két fél közti szárazföldi összeköttetés elégtelensége. A Haburnál található határátkelőnél például a török hatóságok szigorú ellenőrzési szabályai (például katonaság bevonása a folyamatba az állandó biztonsági kihívások miatt) olykor komoly időveszteséget jelentenek a kereskedők számára. ${ }^{41}$

2011-ben az erbili török konzul így nyilatkozott a törököknek a Kurdisztáni Autonóm Régióban tapasztalható jelenlétéről: „Erbilben nagyjából öt török bankkal, 17 török iskolával, 600 török építőipari vállalattal és 17000 török állampolgár folyamatos jelenlétével számolhatunk, valamint napi szinten közvetlen légiforgalom is zajlik Törökország és az iraki kurd régió között. Erre a két ország közti turizmus révén még inkább szükség mutatkozik. Az Irak és Törökország közti teljes kereskedelem összege 12 milliárd dollár, aminek több mint 70\%-a a KAR-hoz kapcsolódik. A külföldi eredetü, iraki kurd régióban bejegyzett cégek fele török." ${ }^{42}$ 2011-ben a KAR importjának nagyjából 85\%-a Törökországból érkezett, ${ }^{43}$ ez pedig mintegy 5,5 milliárd dollárt tett ki. Ezzel a KAR Törökország nyolcadik legnagyobb exportpiaca lett. ${ }^{44}$ Mindezen adatok tükrében nem meglepő, hogy az iraki kurdok által használt élelmiszerektől a bútorokig, a legfontosabb fogyasztási cikkek túlnyomó része a török ipar termékének tekinthetö. ${ }^{45}$

Fontos megjegyezni, hogy a Törökország és a Kurdisztáni Autonóm Régió közti kereskedelmi kapcsolatokban nem csupán az államtól „független” magánszektor érdekelt, hanem komoly üzleti kapcsolat mutatható ki a török és az iraki kurd vezetés között is. Valójában a két fél közötti kiváló kapcsolat nagyban függ a két kormánypárt, a török AKP és az iraki kurd KDP társadalmi beágyazottságától és politikai sikerétől: egymás politikai támogatása tehát a virágzó gazdasági együttmüködés záloga. Az Ankara és Erbil közti kapcsolatok javulásában az is fontos szerephez jutott, hogy mindkét állam hasonló politikai-gazdasági rendszerrel rendelkezik, ahol az üzleti tevékenység és a politika szorosan összefonódik (oligarchikus kapitalizmus), minthogy a politikusok maguk is komoly gazdasági hátországgal rendelkeznek. ${ }^{46} \mathrm{Az}$ iraki kurd politikusok például az olaj eladásából származó jövedelmekre

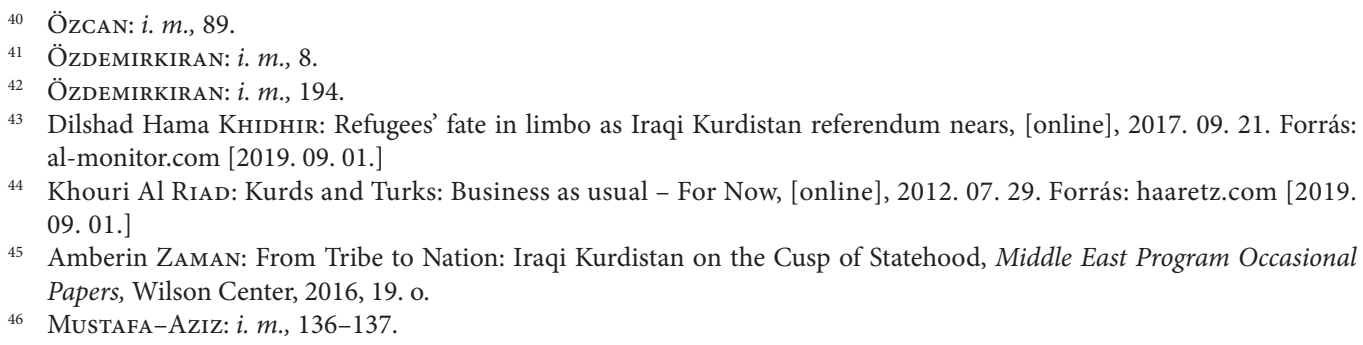

44 Khouri Al RiaD: Kurds and Turks: Business as usual - For Now, [online], 2012. 07. 29. Forrás: haaretz.com [2019. 09. 01.]

45 Amberin Zaman: From Tribe to Nation: Iraqi Kurdistan on the Cusp of Statehood, Middle East Program Occasional Papers, Wilson Center, 2016, 19. o.

46 Mustafa-Aziz: i. m., 136-137. 
rátéve a kezüket maguk is üzletemberekké váltak, és ekképpen a Törökországgal kapcsolatban kialakított politikát gazdasági érdekeik szolgálatában is felhasználják. ${ }^{47}$

\section{Energiapolitikai kapcsolatok}

A kereskedelmi tevékenység és a bilaterális gazdasági kapcsolatok egyik legjövedelmezőbb részét a Törökország és a Kurdisztáni Autonóm Régió közti energiapolitikai együttmüködés teszi ki. Az energiaszektoron belül a KAR adottságainak és potenciáljának megfelelően a legnagyobb szerepet a kőolaj és a földgáz kereskedelme, illetve az ezekkel az energiahordozókkal kapcsolatos megállapodások kapják.

A KAR nem csupán politikai, hanem gazdasági, illetve energiapolitikai szempontból is sajátos - bár a Közel-Keleten nem egyedi - jelenségnek számít. Az autonóm tartomány ugyanis nem rendelkezik tengeri hozzáféréssel, szomszédjai pedig - beleértve Törökországot is - egyértelmüen elutasítják azt, hogy de jure függetlenné váljon. A tartomány kedvezötlen geopolitikai pozíciója hozzájárul ahhoz, hogy gazdasági értelemben függő helyzetben legyen nem csupán a hagyományos kereskedelmi utakat, hanem az energiahordozók világpiacra juttatását illetően is.

Az erbili vezetés politikai és gazdasági hatalma a Törökországgal kialakított jó viszony megőrzésén áll vagy bukik: Törökország kínálja ugyanis az egyetlen racionális irányt az iraki Kurdisztánban kitermelt energiahordozók (kőolaj és földgáz) exportjához. A „szomszédok" közül Irak központi területe és Irán is a kőolaj- és földgázszektorban a kurdok vetélytársa, mindketten a regionális és globális energiapiac résztvevői, míg Törökország maga is felvevőpiac, illetve a nyugati fogyasztók felé a lehető legkedvezőbb (legrövidebb, legbiztonságosabb) útvonalat biztosítja az energiahordozók számára.

Önmagában, gazdasági szempontból nézve az iraki kurd autonóm tartomány egy tipikus közel-keleti járadékgazdaság (rentier state vagy resource economy), vagyis költségvetésének nagy részét az energiahordozók eladásából (és nem adókból) nyeri, és e bevételek birtoklása, illetve lefölözése az uralkodó osztály hatalmának egyik legfontosabb bázisa. ${ }^{48}$ A KRK vezetése a kiterjedt állami (pontosabban a párthoz kötődö) struktúrák révén alkalmazott munkaerő támogatásával szerzi meg a lakosság támogatását (patrónus-kliens viszony). Ebben a rendszerben az államhoz (pontosabban a párthoz) való kapcsolódás foka és nem az egyéni képességek lesznek a kiválasztás és a társadalmi felemelkedés alapjai, így a nepotizmus és a korrupció a rendszer lényeges elemeivé válnak. Minthogy az állam sikere és bevételeinek döntő hányada a gazdaság egy szektorának teljesítményéből fakad, így a gazdaság más területein a fejlesztések elmaradnak, vagyis alternatív struktúrák, gazdasági diverzifikáció megvalósítására nem nyílik lehetőség.

\footnotetext{
47 E tekintetben érdemes felhívni a figyelmet a KDP-hez köthető személyek nagyarányú (4 milliárd dollár nagyságrendű) törökországi befektetéseibe és gazdasági érdekeltségeire is. Alex DANILOvicH: Iraqi Federalism and the Kurds. Learning to Live Together, Routledge, Ashgate, 2014, 128. o.; Az iraki Kurdisztánba irányuló üzleti tevékenység egyébként a török társadalom teljes ideológiai palettáját megmozgatta. Így például az 1990-es évek közepétől a Hizmet mozgalom révén több mint 20 általános és középiskolát hoztak létre a KAR területén, amelyekben angol nyelven oktattak, de kurd, török és arab választható tantárgyak is voltak. 2008-ban a mozgalom támogatásával létrejött az Észak-Iraki Egyetem is. Fuller: i. m., 325.

48 Irak egész területére nézve az olajiparból származó exportbevételek a külfölddel folytatott teljes kereskedelemnek a $98 \%$-át adják.
} 
A KAR-ban található erőforrásokat illetően eltérő adatok láttak napvilágot, ugyanakkor a tartomány kiterjedt potenciáljához nem fér kétség. A Természeti Erőforrások Minisztériuma szerint a tartományban 45 milliárd hordónyi kőolajtartalék van, ami a vitatott területek hozzáadásával állítólag 70 milliárd hordónyira nő. Ezzel szemben a Nemzetközi Energiaügynökség (IEA) jelentése 2012-ben 4 milliárd hordónyi mennyiség meglétéről adott számot. ${ }^{49}$

2007-ben, miután a központi kormányzat képtelen volt megfelelő törvényi hátteret biztosítani a kőolaj és földgáz kitermeléséhez, a KRK a kérdés szabályozását saját kezébe vette, és önálló kőolaj- és földgáztörvényt alkotott. ${ }^{50}$ 2007. augusztus 6-án az iraki kurd parlament ratifikálta az új Tartományi Szénhidrogén Törvényt, amelyet viszont Bagdad azóta sem hagyott jóvá. ${ }^{51} \mathrm{~A}$ szénhidrogéntörvény az iraki központi területeken érvényben lévő szabályozás helyett sokkal kedvezőbb feltételeket biztosít a befektetők számára, minthogy ennek keretében lehetőség van a nemzetközi befektetőkkel való profit és befektetett eszközök megosztására. Bagdad szabályozása szerint ugyanis a nemzetközi befektetők nem részesülhetnek a befektetett eszközök, illetve a kitermelt kőolaj és földgáz felett, hanem csupán a nyereségből kapnak meghatározott részesedést. ${ }^{52}$

2011 novemberében nagy áttörést hozott, hogy az ExxonMobil, a világ legnagyobb nem állami olajipari vállalata megkezdte iraki kurdisztáni tevékenységét, amelyet nem sokkal később a Chevron KAR-beli megjelenése követett. ${ }^{53} \mathrm{Ez}$ a fajta nemzetközi elismerés komoly ellentéteket generált Bagdad és Erbil között. A két kormányzat amúgy is egymás versenytársává vált a nemzetközi befektetők kegyeiért való harcban. Ennek keretében a központi kormányzat - nem minden esetben konzisztens módon - a külföldi kőolaj- és földgázipari befektetőket választás elé állította: vagy a KAR területén fektetnek be, vagy pedig Irak többi területén. Míg az ExxonMobil és a Chevron esetében Bagdad alkalmazta ezt a fenyegetést, a Totalt és a Gazpromot csupán figyelmeztette, hogy az Erbillel kötött szerződéseiket jogszerütlennek tekintik. ${ }^{54}$

Az Irak és Törökország közötti kőolaj-infrastruktúrát az iraki Kirkuk és a törökországi mediterrán kikötő, Ceyhan között kiépült, 1977-ben átadott Kirkuk-Ceyhan (vagy másnéven Kirkuk-Yumurtalık) kőolajvezeték képviseli. Ez ebben a viszonylatban egyedüli

49 ZAMAN: i. m., 13.

50 Massimo Morelli - Costantino Pischedda: The Turkey-KRG Energy Partnership: Assessing Its Implications, Middle East Policy, 21. évf., 2014/1, 108

51 A kurdok ugyanakkor kettős játékot játszanak: míg saját szénhidrogéntörvényük alkalmazása miatt vitában állnak Bagdaddal, addig a kurd képviselők az iraki parlamentben blokkolják a központi kormány azon törekvését, hogy Irak számára elfogadjanak egy átfogó, szénhidrogénekre vonatkozó törvénycsomagot. Az iraki kurdok egy decentralizált iraki olajipar müködtetésében érdekeltek, és a természeti erőforrásokkal történő gazdálkodásban minél kiterjedtebb jogkörökre pályáznak. Bill PARK: Turkey-Kurdish Regional Government Relations After the U.S. Withdrawal from Iraq: Putting the Kurds on the Map? Strategic Studies Institute, 2014, 121. o.

52 Phillips: $i$. m., 15.

53 ZAMAN: $i . m ., 14$.

54 Morelli-Pischedda: $i$. m., 121.; Az iraki alkotmány egymásnak ellentmondó passzusai mindkét fél érvelését alátámaszthatják. 
vezetékként az iraki olajexport északi, illetve nyugati áramlását biztosítja. ${ }^{55} \mathrm{Az}$ 1991-es háború után a müködésében többször is leállás következett, míg 1995-től az olajat élelmiszerért programban ${ }^{56}$ jutott kiemelt szerephez. A vezetékkel kapcsolatos problémák hozzájárultak ahhoz, hogy már ekkor elindult az észak-irakiak segítségével az olaj teherautókon történő szállítása Törökországba. A 2003-as amerikai megszállás utáni, az északiraki területeken elharapódzó erőszak elsősorban a Törökország felé irányuló kőolajinfrastruktúrában tett kárt, illetve okozott az ellátásban nehézségeket, míg a dél-iraki vezetékek és finomítók sértetlenül müködhettek. ${ }^{57} \mathrm{~A}$ problémák később sem enyhültek: 2013-ban például legalább tíz támadás történt a Kirkuk-Ceyhan vezeték ellen az iraki szakaszon, háromszor pedig technikai problémák miatt kellett a vezeték müködését leállítani. ${ }^{58}$ A Kirkuk-Ceyhan-vezeték rövid története is mutatja tehát, hogy a biztonsági környezet és a karbantartás hiányosságai a vezetéket jelenleg nem teszik alkalmassá hosszú távú, kiszámítható és stabil kőolajszállításra Irak és Törökország között. A problémát az is fokozza, hogy a Törökország és a KAR közti közvetlen energiakapcsolatok kialakítását nem teszi lehetővé ez a vezeték, mivel az a központi kormány ellenőrzése alatti területeken, valamint a vitatott területeken is áthalad. Amennyiben tehát Törökország a KAR területéről nagyobb mennyiségben kőolajat kíván beszerezni, úgy új, közvetlen szállítási útvonalakat kell kiépítenie.

Irak a becslések szerint mintegy 3,4 trillió köbméternyi földgázkészlettel rendelkezik, amelynek legnagyobb része a hagyományosan is a kőolajtermeléséről ismert déli területeken helyezkedik el. Az iraki háború következményeképpen azonban mind a termelésben, mind az infrastruktúrában komoly károk keletkeztek: míg 2000-ben az éves földgáztermelés világviszonylatban is alacsony, mintegy 3,2 bcm $^{59}$ volt, addig ez 2012-ben a rendkívül elenyésző mértékű 0,9 bcm-re esett vissza. ${ }^{60}$ Ilyen termelési eredmények mellett nem meglepő, hogy a mai napig nem épült ki földgázt szállító infrastruktúra Irakból Törökországba.

A háborút követően Törökország egyre növekvő földgázigényére reagálva 2008-ban a török és az iraki kormány között létrejött egy egyetértési nyilatkozat az úgynevezett

55 A 965 km-es vezeték törökországi szakasza a török-iraki, illetve a török-szír határral párhuzamosan fut, és eredeti kapacitását (750 ezer hordó/nap) 1984-re 1 millió hordó/napra növelték, míg 1987-ben a párhuzamosan futó második vezetéket is átadták, így a teljes kapacitás a napi másfél millió hordót is elérhette. Ghanim AnAz: Iraq. Oil and Gas Industry in the Twentieth Century, Nottingham University Press, 2012, 397-401. o.; A bővítésnek köszönhetően a Kirkuk-Ceyhan vezeték a legnagyobb iraki vezeték lett. Rafael Kandiyoti: Pipelines: Flowing Oil and Crude Politics, I. B. Tauris, 2012, 71-72. o.

56 Minthogy az 1990-es években a gazdasági embargó miatt a kurd területek jelentős termékimportra szorultak, a helyi gazdaság komoly dilemmával nézett szembe. A fizetőképes helyi valuta híján lévő iraki kurdok számára az 1995-ben induló „olajat élelmiszerért” (Oil-for-Food) program jelentette az egyetlen kiutat a Törökországgal és Iránnal szembeni kereskedelmi mérleg rendkívül kedvezőtlen alakulásából. Ennek keretében az egyetlen nemzetközileg is értékelhető helyi terméket, az olajat kamionokkal szállították Törökországba, míg onnan cserébe élelmiszer érkezett. Charles G. MACDonald - Carole A. O'Leary (szerk.): Kurdish Identity. Human Rights and Political Status, University Press of Florida, 2007, 143. o.

57 MacDonald-O'Leary: i. $m ., 80$.

58 Till F PaAsche - Howri Mansurbeg: Kurdistan Regional Government-Turkish energy relations: a complex partnership, Eurasian Geography and Economics, 55. évf., 2014/2, 118. o.

59 Bcm - a milliárd köbméter angol rövidítése. A British Petrol 2016-os jelentése szerint például Magyarország 2015-ben 8,9 bcm földgázt fogyasztott. Mark SMedLeY: Gazprom holds talks with Hungary, [online], 2016. 06. 17. Forrás: naturalgasworld.com [2019.09. 10.]

60 Simone Tagliapietra: Turkey as a Regional Natural Gas Hub: Myth or Reality? An Analysis of the Regional Gas Market Outlook, beyond the Mainstream Rhetoric, Fondazione Eni Enrico Mattei, 2014, 13-15. o. 
ITGEP (Iraq-Turkey Gas Exportation Project) megvalósításáról. A cél 10-12 bcm gáz szállítása lett volna, ám úgy tünik, a központi kormányzat részvétele helyett jelenleg nagyobb esély mutatkozik arra, hogy a projekt az iraki kurdok és Törökország közötti együttmüködés keretében jön létre. Ennek oka, hogy a török-iraki kapcsolatokban a 2010-es iraki választások és az azt követő fejlemények komoly fordulatot hoztak. A kormányt alakító Núri al-Maliki miniszterelnök rossz néven vette, hogy a választások során Törökország egyértelmü támogatásáról biztosította ellenlábasát, Ayad Allawit. A Maliki-kormány egyre inkább Irán támogatását keresve síita-párti politikát alakított ki Irakban, aminek a szunnita miniszterelnök-helyettes, Tarek al-Hasemi is áldozatul esett volna, ha előbb Erbil, majd Ankara nem nyújt neki menedékjogot. Ebben a feszült helyzetben kezdte meg Törökország a KAR területéről történő olajszállításokat, ami Ankara és Bagdad végleges eltávolodásához vezetett. ${ }^{61}$ A szállítások tartálykocsikkal történtek, minthogy a már meglévő KirkukCeyhan kőolajvezetéket a biztonsági kockázatok és a bagdadi kormány ellenkezése miatt nem használhatták. ${ }^{62}$

2012 áprilisában az Erbil és a Bagdad közötti viszony új színezetet kapott: Erbil leállította a központi kormány számára (a központi export-vezetékrendszerbe) történő olajszállításokat, mivel 2011 májusa óta Bagdad nem fizette ki a KAR területén működő olajvállalatok részesedését. Erbil nem csupán azzal vádolta Bagdadot, hogy a megállapodásnál kisebb összeget fizetett ki, hanem azzal is, hogy mindezt többszöri utalással, kisebb részletekben teljesítette, így meglehetősen nehézzé teszi a politikai és gazdasági ügyek tervezését a KARban. Bagdad szerint azonban az is közrejátszott ebben, hogy a KAR-ból érkező, exportra szánt kőolaj kevesebb a vártnál, mivel abból helyi szinten elvonás történik. A vitában a KAR vezetésének is meg volt kötve a keze, ugyanis a központi kormányzat által átutalt pénz hiányában nem képes kifizetni az olajcégeknek járó részt. Hiába történt megállapodás a két fél között 2012 szeptemberében, kevesebb mint három hónap múlva a kifizetetlen számlák miatt a KAR újra beszüntette a Bagdad felé való olajszállítást. ${ }^{63}$

Ankara és Erbil között 2012 májusában megszületett az egyezség arról, hogy a KAR és Törökország között egy gázvezetéket és két új kőolajvezetéket építenek. ${ }^{64} \mathrm{Ez}$ a megegyezés először egy olyan kőolajvezeték üzembe helyezését vizionálta (2014-re), amely napi 1 millió hordós kapacitásával az iraki központi kormánytól független iraki kurd olajexport-kapacitást tenne lehetővé. A vezeték terve egyébként az évtizedek óta tartálykocsikkal a határon keresztül történő kőolajszállítás „intézményesítéseként” is értelmezhető. Mind az új kőolaj-, mind pedig az új földgázvezetékek a Kurdisztáni Autonóm Régió felemelkedő

61 Tol: $i . m ., 4$.

62 A kamionokkal történő úgynevezett light crude exportálását ugyan Bagdadból illegálisnak tartják, annak büntetését korlátozta az a tény, hogy a szállításban érdekelt volt a világ két nagy vezető kereskedőháza, a Trafigura és a Vitol is. DANilovich: i. m., 129.; Az olajszállítások tartálykocsikon egyébként Irán felé is müködnek, rendkívül nyomott áron. Patrick Osgood - Kamaran AL-NAJAR: Kurdistan Exports Nearly Zero as Payment Hopes Thin, Iraq Oil Report, 2012. december 20.

63 Morelli-Pischedda: i. m., 109.; Bárhogy is áll a helyzet, az bizonyos, hogy Bagdad és Erbil erőforrásjátszmáinak fenntartásában mindkét fél elitje érdekelt lehet, hiszen a Bagdadból ki nem fizetett részesedés vagy a kifizetett részesedés és a valós részesedés különbözete, illetve a KAR-ból „visszatartott” olajmennyiségek mind az elvonásokból közvetlenül részesülő kormányzati és gazdasági köröket gazdagítják. DANıLOvich: i. m., 130.

${ }^{64}$ Az egyezség valójában nem két kormány között közvetlenül született, hanem a Genel Enerji mint magáncég és a KRK képviselői között. A Genel Enerji azonban a török kormány támogatását élvezi, tevékenységével pedig egyértelmüen Ankara érdekeit szolgálja a KAR területén. 
szénhidrogénszektorának bővítéséhez technikailag is szükségesek, ugyanakkor politikai szempontból is jelentősek. Ezek a stratégiailag fontos vezetékek gazdasági hasznuk révén a KAR bagdadi kormánytól való politikai függetlenedési törekvését is szolgálhatják. Erbil számára pedig ez az egyetlen lehetőség a nemzetközi piacokra való kijutáshoz, illetve önálló bevételi források megszerzéséhez. Ráadásul Törökország pozíciója Erbil számára a Nabucco-gázvezetékhez történő csatlakozás, vagyis az európai piacra juttatott földgáz lehetőségével is kecsegtetett (egészen a Nabucco-projekt 2013. júniusi lezárásáig). Míg ez az Ankara és Erbil közti 2012-es megegyezés Bagdad és Erbil között nyilvánvalóan tovább erősíti a feszültséget, azt is fontos látni, hogy az ehhez hasonló közös energiapolitikai projektek a megvalósítás után a politikai manőverezés (a kapcsolatok ingaszerü kilengésének) lehetőségét egyre inkább visszavetik, így Ankara és Erbil viszonylatában stabil és kiegyensúlyozott kapcsolatokhoz járulnak hozzá. ${ }^{65}$

Egy újabb, 2013 novemberében Ankara és Erbil között létrejött megállapodás értelmében 2017-re 4 bcm, 2020-ra 10 bcm, majd a későbbiekben összesen 20 bcm földgázt szállítanak az autonóm tartomány területéről Törökországba. ${ }^{66} \mathrm{~A}$ kapcsolatok mindkét félnek előnyösek: az iraki kurdok nemzetközi elismerése Törökország támogatásával megnő, míg Ankara számíthat az iraki kurdok közbenjárására abban, hogy a törökországi kurdok (PKK) ne zavarják a létfontosságú kelet-törökországi energia-infrastruktúrát. A Kurdisztáni Autonóm Régióból potenciálisan érkező kőolaj és földgáz Törökország növekvő energiaigénye ${ }^{67}$ számára kiemelt fontosságú, ráadásul nemcsak az ország növekvő energiaigényének fedezését szolgálja, hanem a diverzifikációs igényeknek is eleget tesz. A KAR befektetésbarát politikája és az Irak többi részéhez képest tapasztalható kisebb biztonsági és politikai kockázat ugyancsak komoly súllyal esett a latba, amikor Ankara energiapolitikai szempontból is Erbil mellett kötelezödött el Irakban. A földgázra vonatkozóan ráadásul az is előnyös Törökország számára, hogy a KAR területén nagyobb földgázkészlet található annak köszönhetően, hogy a nemzetközi vállalatok eddig sokkal kevesebb feltáró munkát végeztek. Ráadásul a KAR geopolitikai kiszolgáltatottsága révén állítólag a földgázt Törökország számára sokkal olcsóbban (az oroszok által a törököknek szállított földgáz árának harmadáért) fogja szállítani.

\section{Az Ankara és Erbil közti kapcsolatok regionális keretrendszerben}

A törökökkel való kapcsolatok eleinte gazdasági, majd politikai (illetve az energiapolitikai megállapodásokkal stratégiai) szinten történő elmélyülése Erbil számára - amely mindvégig az amerikai támogatásra támaszkodott - az amerikai kivonulás (2011) utáni időszakra gondolva racionális lépésnek tekinthető. Abból a szempontból is érthető ez a változás, hogy

65 Ezen túlmenően az is kiemelendő, hogy bár Törökország irányában a létező vagy potenciális szállítási infrastruktúra a KDP által ellenőrzött területeken halad át, a legtöbb földgázmező a PUK területein található. Annak érdekében tehát, hogy a KAR jelentős földgázipari szereplővé váljon, nem csupán Törökországgal kell az együttműködést mélyíteni, hanem a két iraki kurd párt közti együttmüködésnek is új dimenziót kell adni. ZamaN: $i$. m., 14.

66 TunÇAlP: i.m., 73.

67 Ez 1990 és 2008 között évente átlagosan 4,3\%-kal nőtt. A földgázt illetően 2000-től 2013-ig a fogyasztás megháromszorozódott Törökországban (15 bcm-ről 47,6 bcm-re). Ennél nagyobb arányú változás ebben az időszakban csak Kínában történt a földgázfogyasztásra vonatkozóan. DudLÁk Tamás: Törökország helye az Európai Unió, Oroszország és Azerbajdzsán közti gázjátszmában, Világpolitika, 2. évf., 2017/1, 60-79. o. 
az iraki kurdoknak a legkomolyabb vitás kérdéseik az iraki arabokkal (központi kormányzat) voltak, míg ehhez a viszonyhoz képest Törökország a kisebbik rossznak számított ebben a kihívókkal és vetélytársakkal teli környezetben. ${ }^{68} \mathrm{Az}$ iraki kurdok számára a regionális patrónus szerepre Törökország azért is a megfelelö, mert Európához és a Nyugathoz is közel áll mind földrajzi, mind pedig ideológiai értelemben. Az iraki kurdok körében amúgy is jellemző a Nyugat-párti irányvonal, és ezt a kormányzat a nyugati befektetőknek tett előnyös ajánlatokkal is megerősítette. ${ }^{69} \mathrm{~A}$ teheráni-bagdadi-damaszkuszi tengelybe való betagozódás a nyugati hatalmak szemében elszigetelődéshez vezetett volna, amely ráadásul nemcsak a nyugati hatalmak, hanem akár a közvetlen szomszéd, Törökország haragját is magára vonhatta volna.

Ha tehát a két fél között megélénkülő kapcsolatok hozadékát nézzük, az iraki kurdok számára a török kapcsolat és támogatás növeli az autonóm tartományuk nemzetközi elfogadottságát, míg a másik oldalon Ankara befolyásának növekedése Észak-Irakban Törökország regionális hatalmi pozíciójának erősítését jelenti. ${ }^{70}$ Ankara eszerint egy stabil, erős és megbízható KAR létében érdekelt, amely annyira autonóm, hogy lehetővé teszi a török befektetők térnyerését a tartományban. Az autonóm jogkörök kiterjesztése egy bizonyos ponton túl azonban már Ankara érdekeivel ellentétes. ${ }^{71}$

A KAR-ral szemben Irak többi területén Törökország számára kevésbé nyílik lehetőség a gyümölcsöző együttmüködésre - s ez az állítás különösen igaznak bizonyult mind a turkománok, mind a szunnita politikai csoportosulások bagdadi befolyásának csökkenése után (2010 után). Az iraki kormánnyal való politikai feszültségek (síita befolyás, iráni támogatás) annak megnyilvánulásaiként is értelmezhetők, hogy Bagdad az amerikai kivonulást követően Ankara számára a Közel-Keleten zajló geopolitikai játszma ellentétes oldalára került. Az utóbbi évek regionális fejleményei az egymással szembenálló érdekek mentén politizáló tömböket a már eddig is létező törésvonalak kiélezésével még inkább eltávolította egymástól. A központi Irakot az iraki kurdokhoz képest más geopolitikai realitások mozgatják: politikai elköteleződése és világpiaci nyitottsága miatt Bagdad kevésbé kiszolgáltatott Törökország irányában, mint a csak szárazföldi határokkal rendelkező kurd tartomány, amely mostanra gazdaságilag és energiapolitikailag is döntően Törökországhoz kötődik.

A török külpolitika iraki váltásából regionális szinten egy további kényszerü elemet is kiolvashatunk: míg az amerikai csapatkivonást követően Irán egyszerüen csak korábban

68 Simon A. Waldman - Emre Caliskan: The New Turkey and its Discontents, 2016, C. Hurst \& Co., 2016, 216. o.; Irán 2011 nyarán komolyabb offenzívát hajtott végre az iráni kurdok egyik legfőbb képviselőjének számító PJAK ellen, amely az iraki kurdok számára is intő jel volt arra nézve, hogy az amerikaiak év végi iraki kivonulása után szükségük van Irán befolyásával szemben - amely Bagdadban még inkább éreztette magát - egy új védnökre - ez pedig kizárásos alapon a régióban Törökország lehet. Ahogy a gyakran idézett kurd közmondás tartja: „A kurdoknak nincsenek barátaik, csak a hegyek.” A jelenlegi nemzetközi térben a kurd függetlenségnek és a kurdok gazdasági és politikai felemelkedésének ugyan akadnak elvi támogatói, a gyakorlatban a nemzetközi rendszer szereplői a status quo fenntartásában érdekeltek, ami pedig a legfőbb (iraki) kurd politikai cél, az önrendelkezés megszerzése elleni állásfoglalást jelent.

69 Mustafa-Aziz: i. m., 136.

70 PaAsche-Mansurbeg: $i$. m., 2.

71 Ebből a szempontból a határ egyértelmű meghúzása a gyakorlatban igencsak nehézkes: mert ugyan az egyértelmű, hogy Ankara nem támogatja a KAR Iraktól való függetlenedését, mégis a szoros gazdasági kapcsolatokkal anyagi alapot teremt a függetlenséghez, míg a szoros stratégiai kapcsolatok révén szintén az önállóság irányába tolja Erbilt, amennyiben az hozzájárul az Erbil és Bagdad közti elhidegüléshez. 
megszerzett előnyös helyzetére reagált azzal, hogy a bagdadi kormányra gyakorolt befolyását tovább építette, ${ }^{72}$ addig az ekképpen Bagdadból kiszoruló török politikának új utat $^{73}$ kellett magának keresnie ahhoz, hogy valamiféle befolyása az iraki ügyekre megmaradhasson. Ez a regionális realitás újabb ösztönzőt adott tehát Ankara számára ahhoz, hogy Erbillel eddig kialakított kapcsolatait még inkább elmélyítse. ${ }^{74}$ A török külpolitika célja tehát Irakban az, hogy az országot (és föképpen iraki Kurdisztánt) gazdaságilag és politikailag egyre közelebb vonja magához, ezzel is csökkentve a regionális vagy globális versenytársak (Irán, Oroszország, Szaúd-Arábia) ${ }^{75}$ befolyását.

Törökországnak a KAR-val való stratégiai kapcsolatai a Közel-Kelet szektariánus (szunnita-siita ellentét) olvasatába is beleillik; eszerint Törökország és a KAR egy északi, szunnita tengelyt alkot az Irán, Szíria és központi Irak vezette síita „félholddal” szemben. ${ }^{76}$ Ennek az értelmezésnek ugyanakkor nem kell túlzottan nagy magyarázó erőt tulajdonítani a regionális szereplők egymás közti kapcsolatrendszerében. A KAR esetében a szektariánus magyarázat még kevésbé alkalmazható, az ugyanis identitását elsősorban nem polgárainak szunnita kötődésében határozza meg, hanem azok kurd mivoltában. Tény azonban, hogy a Szaddám-rendszer bukása óta újra egyre erősebben jelentkező szektariánus ellentétek Irakban Törökország számára veszélyforrást jelentenek, és a szektarianizmusnak a politikai vezetés szintjére emelkedése (szunnitákkal szemben erősen fellépő síita kormány) Ankara iraki pozícióvesztéséhez járul hozzá. Törökország számára a KAR a stabilitás bástyájaként is szolgálhat a szomszédos Irakban, hatékony pufferzóna szerepét töltheti be az iraki szektariánus ellentétek Törökországot érintő hatásának csillapításában. ${ }^{77}$

Irán az iraki kurdokkal kapcsolatosan hasonló egyensúlyozó politikát követ, mint Törökország, a határokon átnyúló kereskedelem azonban jóval kisebb mértékủ (nagyjából fele), ${ }^{78}$ mint Ankara és Erbil között. Az utóbbi két évtizedben azonban Irán és a KAR közti kereskedelmi volumenben is nagyarányú növekedés történt: míg 2000-ben ez csupán évi 100 millió dollárra rúgott, addig a 2014-es 4 milliárd dolláros kereskedelmi forgalom Törökország után Irán számára biztosítja a második helyet a KAR legnagyobb kereskedelmi partnerei között. ${ }^{79}$ Míg Irán pragmatikus gazdasági kapcsolatokat ápol a KAR-val, addig az iráni kurdok számára Teherán nem hagy esélyt bármiféle autonómia kivívására. Ankara és Teherán (illetve Bagdad) között tehát az iraki kurdok függetlenségének elutasítá-

72 Ezzel ugyanakkor Irán bagdadi elköteleződésének foglya maradt, ami az Erbillel kialakított kapcsolatokban korlátozó tényező lehet számára.

73 Vagyis a már említett, iraki turkománokon és szunnita arabokon túlmutató politikai szövetségeket vagy proxykat.

74 William Gourlay: Mesopotamian Nexus: Iran, Turkey, and the Kurds. In: Shahram AkbarzadeH - Dara Conduit (szerk.): Iran in the World. President Rouhani's Foreign Policy, Palgrave Macmillan, 2016, 118. o.

75 A szaúdi külpolitika igyekszik a regionális ellentéteket vallási színezetben feltüntetni, holott Irak felemelkedése nem vallási, hanem geopolitikai szempontból jelenthetne kihívást Szaúd-Arábia számára, amely - Iránnal ellentétben - nem rendelkezik számottevő befolyással Irakban. Ekképpen a jelenlegi feszült, szektariánus ellentétekkel tarkított helyzet kedvező a monarchia számára, míg a legoptimálisabb eredményt egy szunnita, Irán-ellenes bagdadi kormány pozícióba jutása jelentené. Fuller: i. m., 296.

76 Charountaki: i. m., 197.

77 Phillips: $i$. m., 2.

78 FUller: $i . m ., 328$.

79 Costas Laoutides: How Foreign Is the Kurdish Issue in Iran's Foreign Policy? In: Shahram AkbarzadeH - Dara Conduit (szerk.): Iran in the World. President Rouhani's Foreign Policy, Palgrave Macmillan, 2016, 100. o. 
sában egyetértés mutatkozik, ugyanakkor a KAR területe mindannyiuk számára a politikai és gazdasági versengés színtereként realizálódik.

A török szakirodalomban csak az Ankara-Bagdad-Erbil háromszögnek nevezett konstelláció szereplöi közti dinamika legalapvetőbb meghatározója az egyensúly fenntartása; ennek megtalálása pedig meglehetősen kényes feladat egy ennyire dinamikusan változó külső (regionális, globális) és belső (iraki) környezetben. Az egyensúlyozás politikáját mindhárom szereplő követi, és a gyakorlatban ez azt jelenti, hogy Bagdad, Ankara és Erbil érdekeik maximalizálása végett a többi szereplővel kapcsolatban csupán szűk keretek között cselekedhetnek. Vagyis például biztonsági szempontból Ankarának az kedvez, ha Irak egységes állam marad (nem válik külön Kurdisztán vagy más területek, például északon a szunniták vagy délen a síiták), ugyanakkor egységes államként nem válik annyira erőssé, hogy kihívást jelentsen Törökország számára (mint korábban a Szaddám-rendszer idején). Jóllehet Ankara az intenzív és szívélyes kétoldalú kapcsolatokkal (és azok gazdasági hozadékaival) éppen a legnagyobb mértékben járul hozzá a KAR függetlenségéhez, Törökország mégis ellenérdekelt abban, hogy Erbil a függetlenség útjára lépjen. Vagyis Törökország támogatja a KAR de facto függetlenségét, de nem támogatja a de jure függetlenséget.

Ankara számára gazdaságilag és politikailag kétségkívül előnyös a KAR-val egyre szorosabbra füzött kapcsolat, mindez nem azon az áron, hogy Bagdad és Erbil között teljes szakadás következzen be. Ez ugyanis a KAR-t a függetlenség felé terelné. Ankarának tehát vigyáznia kell arra a törékeny egyensúlyra, amelyen belül lehetősége van Erbil irányában a pragmatikus, nem „kurd alapú” politikáját folytatni. Amint Erbil függetlenséget szerez, a KAR mint politikai entitás Ankara számára újra a kurdkérdés részeként, ellenségként realizálódik, vagyis a függetlenség következtében fellépő politikai költség felülírja a gazdasági hasznot. Ez az Erbillel folytatott gyümölcsöző kapcsolatok végét és a kemalista típusú biztonságiasítás elvének visszatérését jelentené. Másrészröl a KAR és az iraki kormány közti kapcsolatok teljes megromlása Törökországnak azért sem érdeke, mert úgy a KRK elveszítené költségvetése $90 \%$-át, és az így létrejövő gazdasági és politikai bizonytalanság miatt a török gazdasági szereplők nem tudnák fenntartani aktivitásukat a KAR területén.

Erbil ugyancsak érdekelt a bagdadi kapcsolatok normális fenntartásában, mert egyrészt csak így nyílhat számára lehetőség a vitatott területeken történő energiakitermelésre, másrészt pedig a központi síita kormányzattal közös ellenfele van az észak-iraki radikális szunniták személyében. Minthogy - Izraelt leszámítva - a nemzetközi közösség egyik tagja sem támogatja a KAR függetlenségét, így Bagdad és Erbil egy államon belüli pozíciója is - a rengeteg megoldatlan kérdés ellenére - együttmüködésre és pragmatikus viszonyok kialakítására készteti a feleket. A KRK számára az Irak egészén belüli lét a saját hatalmának meghosszabbításaként is értelmezhető: egy független KAR ugyanis nem rendelkezhetne képviselettel Bagdadban, így a tartományon kívüli lehetőségei jócskán beszükülnének. A KAR-nak leginkább egy gyenge Bagdad az érdeke, amellyel egy államban maradva relatív hatalmi fölénybe kerülhetne (vagyis a függetlenedés ebben az esetben még kevésbé kifizetődő). Érdekes módon a mindenkori KRK-nak a függetlenség ügyét támogatnia kell (belső nyomás az iraki kurd választópolgárok részéről), ám annak megvalósulása a politikai vezetésnek valójában nem feltétlenül érdeke - annak előrelátható gazdasági, politikai 
és vélhetően katonai költségei miatt. A kurd nemzeteszme képviseletével összefüggésben ugyancsak elmondható, hogy bár a KRK-nak érdeke a törökökkel való szoros gazdasági és politikai együttműködés, mégsem támogathatja maximálisan a török kormány esetleges kurdellenes intézkedéseit - még akkor sem, ha azok az ideológiailag és politikailag rivális PKK vagy PYD megsemmisítésére irányulnak. A KRK-nak érdemes a túlzott török függés és az iraki központi kormányzat között egyensúlyoznia, mindkét orientációból a maximumot kihoznia.

Az egyensúlyozás kritériumának betartása az iraki központi kormányzatra is vonatkozik, vagyis Bagdadnak is válogatnia kell az Erbillel kapcsolatos kényszerítőeszközök között: egy az iraki kurdok elleni általános támadás például (történjen az politikai, gazdasági vagy katonai téren) nagy valószínűséggel az Amerikai Egyesült Államok részéről visszatetszést szülne, amely így a status quo visszaállítására szólítaná fel a feleket. Bagdadnak reális érdeke Erbillel szemben az, hogy a tartományban a török befolyás rovására ${ }^{80}$ megpróbálja saját gazdasági és politikai befolyását növelni. Ennek legnagyobb akadálya azonban az, hogy Bagdad nem rendelkezik az ehhez szükséges materiális eszközökkel.

\section{Konklúzió}

A török külpolitika iraki kurdokkal kapcsolatos paradigmaváltása kapcsán realista és liberális elemzési keretben elhelyezhető okokat is figyelembe kell venni. Az előbbiek közé tartoznak azok a török belpolitikai változások, amelyek lehetővé tették a vezetés számára, hogy eltávolodjon a korábbi katonai befolyású paradigmától, így biztosítva a békés együttmüködés lehetőségét, illetve a nagyobb - gazdasági szempontokat is figyelembe vevő - külpolitikai mozgásteret. A törökországi nem állami szereplők viszont ugyancsak hozzájárultak a 2007 után bekövetkező változásokhoz: kereskedők és üzletemberek (a közösségi diplomácia aktív alakítói) voltak azok a résztvevők, amelyek a Törökország és iraki Kurdisztán közötti mindennapos kapcsolatokat elmélyítették, így az állam alatti szint államra gyakorolt konszolidációs hatása (az úgynevezett „kereskedőállam” jelenségének kialakulása) is fontos szempont a változás során, ezt a jelenséget pedig leginkább a nemzetközi kapcsolatok liberális megközelítésével lehetséges leírni. Realista szemszögből pedig a PKK jelentette veszély elleni együttmüködés folyamatos kényszerét, az energiapolitikai és kereskedelmi érdekeket, illetve a regionális pozíciószerzés céljait (a kurdkérdésben Szíriában a KRG segítségével, illetve Irán ellen Irakban) említhetjük. Valójában tehát „idealista és realista indokok tökéletes kombinációja játszott közre” úgy, hogy a külpolitikai váltás ára és haszna is egyensúlyban maradt. ${ }^{81} \mathrm{~S}$ bár Törökország kétségtelenül késve kezdte meg formális kapcsolatait kialakítani a szomszédos Erbillel, 2008 után hatalmas lépésekkel sikerült a lemaradását behoznia.

A Kurdisztáni Autonóm Régióval a 2000-es évek második felében kialakított kapcsolatok a davutoğlui elvek gyakorlati megvalósulásaként is értelmezhetők. Ugyanakkor

\footnotetext{
80 Mivel a Kandil-hegységben a PKK tevékenysége alapvetően az iraki központi kormány riválisa, Törökország ellen irányul, így Bagdadnak ugyanúgy nem áll érdekében a kurd terrorszervezet teljes körű felszámolása, mint ahogy a KRG is a gyakorlatban vonakodik a PKK-nak az iraki területekről történő elüzésétől.

81 ERTEM: i. m., 295.
} 
e meglehetősen idealista elvek a Közel-Kelet mély társadalmi, gazdasági és politikai konfliktusaival szemben folyamatos kihívás elé néznek. A török külpolitika - és benne a KARval kialakított kapcsolatok - ekképpen tehát folyamatosan két strukturális (makroszintü) kihívással szembesül. Ezek pedig fokozottan hatással vannak az Ankara és Erbil közötti 2014 utáni kapcsolatok dinamikájára.

Egyrészt a térségben az utóbbi két évtizedben olyan események (amerikai intervenció, az al-Káida és az Iszlám Állam felemelkedése, arab tavasz, szíriai konfliktus és az abból adódó menekültválság) történtek, amelyek Törökország befolyásától függetlenül, mégis alapvetően alakították át Törökország határon túli kapcsolatait. Ezen „külső” hatások felborították a török külpolitikai vezetés évek, évtizedek alatt kiépített közel-keleti kapcsolatrendszerét, és teljesen új válaszok, új prioritások megfogalmazására késztették Ankarát.

Másrészt Törökország minél mélyebb kapcsolatot alakít ki valamilyen nemzetközi szereplővel, annál inkább részévé válik az azt körülvevő problémahalmaznak. Egy meglehetősen konfliktusos és instabil környezetben ugyanis nem lehetséges minden szereplővel azonos mértékű kapcsolatok kialakítása. Vagyis Törökország aktív közel-keleti szerepvállalása akarva-akaratlanul kiszolgáltatottá tette Ankarát, mivel elkerülhetetlen volt, hogy az elemzett időszak végére Ankarára ne legyenek hatással a régió etnikai és szektariánus alapon megfogalmazott ellentétjei. Ez a kiéleződő helyzet pedig a török vezetést egyértelmü állásfoglalások megfogalmazására készteti, ami a „zéró probléma a szomszédokkal” elv és a multidimenzionális külpolitika végét jelenti.

\section{FELHASZNÁLT IRODALOM}

AKsel, Damla B.- Danış, Didem: Diverse Facets of Europeanization at the Iraqi-Turkish Border. In: BAKLACioĞLu, Nurcan Özgür: Migration, Asylum, and Refugees in Turkey: Studies in the Control of Population at the Southeastern Borders of the EU, Mellen Press, 2014.

Anaz, Ghanim: Iraq. Oil and Gas Industry in the Twentieth Century, Nottingham University Press, 2012.

BALCI, Ali - GürLER, Recep Tayyip - BAYKAL, Zana: Türkiye’nin Irak Politikası 2015. In: Duran, Burhanettin - İNaT, Kemal (szerk.): Türk Dış Politikası Yıllı̆̆ı 2015, SETA Yayınlar, Istanbul, 2016, 64. o.

BALOgh István - Egeresi Zoltán - N. Rózsa Erzsébet - RADA Csaba - SzALAi Máté: Kapacitások és ambíciók: a török közel-keleti külpolitika alapjai, MKI-elemzések, E-2013/9.

Charountaki, Marianna: Turkish Foreign Policy and the Kurdistan Regional Government. Perceptions, 17. évf., 2012/4, 185-208. o.

Danilovich, Alex: Iraqi Federalism and the Kurds. Learning to Live Together, Routledge, Ashgate, 2014. DOI: https://doi.org/10.4324/9781315589800

Demir, Ipek - ZeydanlioĞLu, Welat: On the Representation of 'Others' at Europe's Borders: The Case of Iraqi Kurds, Journal of Contemporary European Studies, 18. évf., 2010/1, 7-23. o. DOI: https://doi. org/10.1080/14782801003638612

DuDLÁK Tamás: A török déli nyitás politikája: Soft power eszközök Afrikában, Afrika Tanulmányok, 12. évf., 2018/1-3, 31-54. o.

DudLÁK Tamás: Törökország helye az Európai Unió, Oroszország és Azerbajdzsán közti gázjátszmában, Világpolitika, 2. évf., 2017/1, 60-79. o.

ERTEM, Helin Sarı: Kuzey Irak’tan 'Irak Kürdistanı'na Ankara-Erbil İlişkilerindeki Dönüşümün Siyasi ve Ekonomik Temeller. In: Oктаv, Özden Zeynep - Erтем, Helin Sarı (szerk.): 2000’li Yillarda Türk Dış Politikası: Fırsatlar, Riskler ve Krizler, İstanbul, Nobel Yayınları, 2015, 293-330. o.

FulLer, Graham E.: Turkey and the Arab Spring: Leadership in the Middle East, Bozorg Press, 2014. 
Gourlay, William: Mesopotamian Nexus: Iran, Turkey, and the Kurds. In: Akbarzadeh, Shahram - Conduit, Dara (szerk.): Iran in the World. President Rouhani's Foreign Policy, Palgrave Macmillan, 2016, 111-131. o. DOI: https://doi.org/10.1007/978-1-137-58577-6_7

Kandiyoti, Rafael: Pipelines: Flowing Oil and Crude Politics, I. B. Tauris, 2012.

KhidHir, Dilshad Hama: Refugees' fate in limbo as Iraqi Kurdistan referendum nears, [online], 2017. 09. 21. Forrás: al-monitor.com [2019. 09. 01.]

KIrIşçı, Kemal: The Transformation of Turkish Foreign Policy: The Rise of the Trading State, New Perspectives on Turkey, 40. évf., 2009/tavasz, 29-56. o. DOI: https://doi.org/10.1017/s0896634600005203

Laoutides, Costas: How Foreign Is the Kurdish Issue in Iran's Foreign Policy? In: AkBARzadeH, Shahram - ConduIt, Dara (szerk.): Iran in the World. President Rouhani's Foreign Policy, Palgrave Macmillan, 2016, 93-109. o. DOI: https://doi.org/10.1007/978-1-137-58577-6_6

Lundgren, Asa: The Unwelcome Neighbour: Turkey's Kurdish Policy, I. B. Tauris, London - New York, 2007.

MacDonald, Charles G. - O'Leary, Carole A. (szerk.): Kurdish Identity. Human Rights and Political Status, University Press of Florida, 2007.

Morelli, Massimo - Pischedda, Costantino: The Turkey-KRG Energy Partnership: Assessing Its Implications, Middle East Policy, 21. évf., 2014/1, 107-121. o. DOI: https://doi.org/10.1111/mepo.12061

MustafA, Sara Salahaddin - AzIz, Sardar: Turkey and the Iraqi Kurdistan. Bonds of Friendship. In: DANILOviCH, Alex (szerk.): Iraqi Kurdistan in Middle Eastern Politics, Routledge, London, 2016.

Osgood, Patrick - AL-NajAR, Kamaran: Kurdistan Exports Nearly Zero as Payment Hopes Thin, Iraq Oil Report, 2012. december 20.

Özcan, Mesut: From Distance to Engagement: Turkish Policy towards the Middle East, Iraq and Iraqi Kurds, Insight Turkey, 13. évf., 2. sz. 2011.

Özdemirkiran, Merve: Soft Power and the Challenges of Private Actors: Turkey - Kurdish Regional Government (KRG) Relations and the Rising Role of Businessmen in Turkish Foreign Policy, European Journal of Turkish Studies, 2015/21. DOI: https://doi.org/10.4000/ejts.5268

PaAsche, Till F - Mansurbeg, Howri: Kurdistan Regional Government-Turkish energy relations: a complex partnership, Eurasian Geography and Economics, 55. évf., 2014/2, 111-132. o. DOI: https://doi.org/10.108 0/15387216.2014.942339

PARK, Bill: Turkey-Kurdish Regional Government Relations After the U.S. Withdrawal from Iraq: Putting the Kurds on the Map? Strategic Studies Institute, 2014. DOI: https://doi.org/10.21236/ada597105

Phillips, David L.: Confidence Building Between Turks and Iraqi Kurds, Atlantic Council, 2009.

RIAD, Khouri Al: Kurds and Turks: Business as usual - For Now, [online], 2012. 07. 29. Forrás: haaretz.com [2019.09. 01.]

ŞAHIN, Mehmet: 'Anadolu kaplanları' Türkiye’yi Ortadoğu ve Afrika'da etkili kılıyor” [Az 'anatóliai tigrisek' a török közel-keleti és afrikai befolyás szolgálatában], Ortadoğu Analiz, 2. évf., 2010/17, 94-99. o.

SMEDLeY, Mark: Gazprom holds talks with Hungary, [online], 2016. 06. 17. Forrás: naturalgasworld.com [2019. 09. 10.]

Tagliapietra, Simone: Turkey as a Regional Natural Gas Hub: Myth or Reality? An Analysis of the Regional Gas Market Outlook, beyond the Mainstream Rhetoric, Fondazione Eni Enrico Mattei, 2014. DOI: https:// doi.org/10.2139/ssrn.2384492

ToL, Gönül: Untangling the Turkey-KRG Energy Partnership: Looking Beyond Economic Drivers, Global Turkey in Europe II, Edizioni Nuova Cultura, 2014.

TunÇALP, Emre: Turkey's Natural Gas Strategy: Balancing Geopolitical Goals \& Market Realities, Turkish Policy Quarterly, 14. évf., 2015/3, 67-79. o.

Waldman, Simon A. - Caliskan, Emre: The New Turkey and its Discontents, C. Hurst \& Co., 2016. DOI: https:// doi.org/10.1093/oso/9780190668372.001.0001

Zaman, Amberin: From Tribe to Nation: Iraqi Kurdistan on the Cusp of Statehood, Middle East Program Occasional Papers, Wilson Center, 2016. 